\title{
Dual roles of ATM in the cellular response to radiation and in cell growth control
}

\author{
Yang Xu and David Baltimore ${ }^{1}$ \\ Department of Biology, Massachusetts Institute of Technology, Cambridge, Massachusetts 02139 USA
}

The gene mutated in ataxia-telangiectasia (AT) patients, denoted $A T M$, encodes a putative protein or lipid kinase. To elucidate the functions of ATM, we disrupted the mouse ATM gene through homologous recombination in mice. Consistent with cellular defects of $A T$ patients, the $A T M^{-1-}$ cells are hypersensitive to $\gamma$-irradiation and defective in cell-cycle arrest following radiation, correlating with a defective up-regulation of $\mathrm{p} 53$. In addition, $A T M^{-1-}$ mouse thymocytes are more resistant to apoptosis induced by $\gamma$-irradiation than normal thymocytes. $A T M^{-1-}$ fibroblasts are inefficient in $G_{1}$ to S-phase progression following serum stimulation and senesce after only a few passages in culture. They have an increased constitutive level of $\mathrm{p}^{2} 1^{\text {CIP1/WAF1 }}$. The ATM protein is therefore critical both for cellular responses to ionizing radiation and for normal cell-cycle progression. $A T M^{+/-}$fibroblasts and thymocytes showed intermediately defective responses to irradiation but no growth defect, suggesting that the increased cancer risk of AT heterozygotes could be attributable to poor checkpoint function.

[Key Words: DNA repair; cell-cycle arrest; p53; p21; cellular proliferation]

Received June 6, 1996; revised version accepted July 26, 1996.

Ataxia-telangiectasia (AT) is an autosomal recessive human hereditary disorder characterized by multisystem defects. These include progressive cerebellar degeneration leading to ataxia, dilated blood vessels /telangiectasia) in the eye and facial area, sensitivity to $\gamma$-irradiation, high incidence of tumorgenesis in the lymphoid system, degeneration of thymus, and deficiency in both humoral and cellular immune responses (Lehmann 1982; Swift et al. 1991; Thacker 1994). Whereas AT patients are relatively rare (about $4 \times 10^{-4}$ ), about $0.5 \%$ of the general population harbors a single mutant allele (Swift et al. 1987, 1991). Significantly, cells derived from people heterozygous for an AT mutation have an intermediate sensitivity to $\gamma$-irradiation, and it has been suggested that heterozygous people have a cancer predisposition about fivefold that of the normal population (Swift et al. 1987, 1991). Therefore, understanding the molecular basis of the AT mutation is of great importance.

AT cells are hypersensitive to DNA damaging reagents, such as $\gamma$-irradiation and restriction enzyme digestion, that can introduce double-stranded DNA breaks (Thacker 1994). Furthermore, the ability of AT cells to arrest in $G_{1}$ following DNA damage is deficient, indicating defects in the cell-cycle checkpoint control (Meyn 1995). Because the induction of the p53 protein after $\gamma$-irradiation is responsible for the arrest at $G_{1}$ checkpoint

\footnotetext{
${ }^{1}$ Corresponding author.
}

(Kuerbitz et al. 1992), studies have been carried out to evaluate the p53 response to $\gamma$-irradiation in human AT cells. The initial study suggested that the p53 response to $\gamma$-irradiation is defective in AT cells (Kastan et al. 1992). However, later studies found either no substantial defect in the p53 response to $\gamma$-irradiation in AT cells or that the p53 response is reduced with a delayed kinetics (Khanna and Lavin 1993; Lu and Lane 1993). Genetic heterogeneity among mutant and control cells may have masked effects.

A gene mutated in all tested AT patients, denoted $A T M$, has been identified recently through positional cloning (Savitsky et al. 1995). The ATM gene encodes a large protein that is similar to a number of large proteins that define a subfamily of kinases including the PI-3 (lipid) kinase (Savitsky et al. 1995). Members of this family contain a highly conserved carboxy-terminal kinase domain (Zakian 1995). Several members of this family, including yeast proteins $\operatorname{Rad} 3, \mathrm{Mecl}$, and Tell, are involved in DNA repair and cell-cycle checkpoint control (Weinert and Lydall 1993; Greenwell et al. 1995; Hari et al. 1995; Morrow et al. 1995; Paulovich and Hartwell 1995). Other members of the family, such as yeast proteins Tor $1 p$ and Tor $2 p$ and their mammalian counterpart FRAP, control cell-cycle progression from the Gl phase into the $S$ phase (Brown et al. 1995). A direct link between this kinase family and DNA repair was provided by the discovery that the DNA-dependent protein kinase (DNA-PK) is a member of this family (Hartley et al. 
1995). It is involved in double-stranded DNA break repair and in lymphocyte V(D)I recombination-a defective DNA-PK leads to severe immunodeficiency in mice (Blunt et al. 1995). If structural homology implies functional similarity, ATM could be involved in a cell-cycle checkpoint responding to DNA damage.

The PI-3 kinase family members, including p110 $\alpha, \beta$, and $\gamma$, phosphorylate inositol phospholipids that are involved in signal transduction pathways (Hunter 1995). Members of the ATM kinase family have so far failed to show any intrinsic lipid kinase activity (Hunter 1995). However, Tor proteins and DNA-PK, as well as PI-3 kinase, display protein kinase activity /Carpenter et al. 1993; Dhand et al. 1994; Brown et al. 1995; Hartley et al. 1995), suggesting that ATM may function as a protein kinase.

To elucidate the mechanisms of defective cell-cycle checkpoint control, neurodegeneration, and immunodeficiency in AT patients, we created mutant mice in which the ATM gene is disrupted through homologous recombination. The $A T M^{-1-}$ mice are viable and have developed immune and other defects similar to certain symptoms of AT patients (Xu et al., this issue). Our study of mouse embryo fibroblasts (MEFs) and thymocytes from mice indicates a dual role of ATM relating to cell-cycle checkpoint control. Following $\gamma$-irradiation, the $A T M^{-1-}$ cells arrest cell cycle poorly and have a defective $\mathrm{p} 53$ response. These characteristics support the idea that ATM is responsible for signaling the p53-mediated cell-cycle arrest that follows ionizing radiation. Similarly, ATM was found to be required for efficient apoptosis of thymocytes following $\gamma$-irradiation, another p53-mediated response. ATM is also required for efficient $\mathrm{G}_{1}$ - to S-phase transition during cell-cycle progression. Furthermore, $A T M^{-1-}$ cells prematurely senesce and their level of $\mathrm{p} 21^{\mathrm{CIP1} / \mathrm{WAF} 1}$ protein is chronically high. Thus, ATM also plays a critical role in cellular proliferation.

\section{Results}

\section{Targeted disruption of the ATM gene in mice}

Because the kinase domain of ATM is frequently mutated in AT patients-alteration of one serine residue in the domain can cause the AT phenotype (Savitsky et al. 1995)-we designed a targeting construct to disrupt conserved sequence in the ATM kinase domain (Fig. 1A,B). To screen for homologous recombination events, genomic DNA isolated from transfected embryonic stem (ES) clones was digested with $\mathrm{BamHI}$ and probed with probe A that was outside the transfected targeting construct, giving a $18-\mathrm{kb}$ germ-line band and a $10-\mathrm{kb}$ mutant band (Fig. 1A-C). Positive ES clones were further confirmed by $\mathrm{BamHI}$ digestion and hybridization to probe $\mathrm{B}$, giving a $18-\mathrm{kb}$ germ-line band and a $4.3-\mathrm{kb}$ mutant band (Fig. $1 \mathrm{~A}-\mathrm{Cl}$.

To generate $A T M^{-1-}$ ES cells, the $A T M^{+1-}$ ES cells were selected with higher concentrations of G418 as described previously (Xu et al. 1996b). ES colonies surviv-

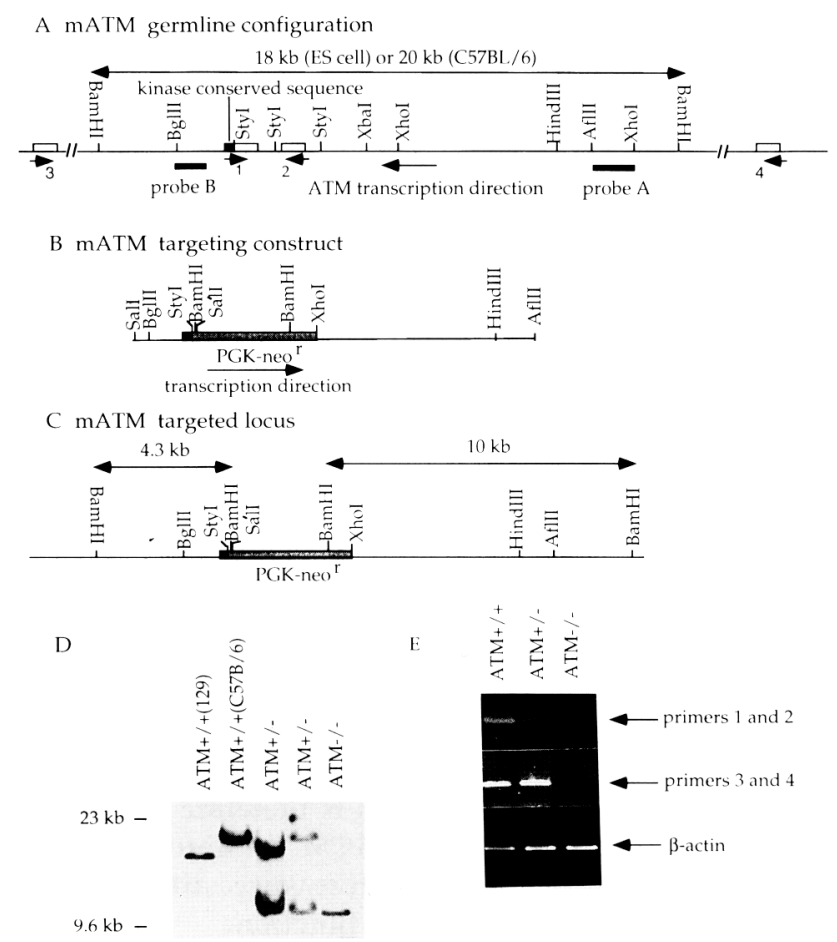

Figure 1. Targeted disruption of the ATM gene in mice. (A) Genomic configuration of the germ-line $A T M$ locus. Exons are represented with open boxes except that the exonal region encoding the conserved kinase sequence is represented with a filled box. The length of the BamHI diagnostic restriction fragment and the locations of the probes are shown. The transcriptional direction of the ATM gene and the locations of the primers are indicated with arrowheads. $(B)$ Targeting construct to insert the PGK-neo ${ }^{r}$ gene into one $A T M$ exon and simultaneously to replace the second exon. The transcriptional direction of the PGK-neo ${ }^{\mathrm{r}}$ gene is indicated with an arrowhead and is opposite that of the ATM gene. $(C)$ Targeted locus following homologous recombination between the targeting construct and the endogenous ATM locus. The lengths of the diagnostic restriction fragments are shown. $(D)$ Southern blot analysis of the tail DNA from $A T M^{+1+}, A T M^{+1-}$, and $A T M^{-1-}$ mice. Tail DNA $(10 \mu \mathrm{g})$ was digested with $B a m H I$ and hybridized to probe A. Because of the polymorphoric nature of the BamHI restriction at this locus, the size of the germline band is either $18 \mathrm{~kb}$ if the allele is derived from ES cells or $20 \mathrm{~kb}$ if the allele is derived from C57BL/6. The locations of the DNA size marker are indicated. (E) RT-PCR analysis of the ATM mRNA in $A T M^{+1+}, A T M^{+1-}$, and $A T M^{-1-}$ MEFs. The amplified products from the synthesized cDNA are correlated with the primers indicated with arrowheads.

ing the selection of $4.8 \mathrm{mg} / \mathrm{ml} \mathrm{G} 418$ were expanded and analyzed by Southern blotting. The $A T M^{-1-}$ ES cells were subcloned and confirmed (data not shown).

Six out of seven $A T M^{+/-}$ES clones injected into blastocysts gave rise to chimeric mice that transmitted the ATM mutation into germ-line. Mice heterozygous for the $A T M$ mutation $\left(A T M^{+1-}\right)$ were intercrossed to generate mice homozygous for the $A T M$ mutation $\left(A T M^{-1-}\right)$. Tail DNA derived from $A T M^{+1+}, A T M^{+1-}$, 
and $A T M^{-/-}$mice were analyzed by Southern blot (Fig. 1D).

Because the ATM gene is expressed ubiquitously (Savitsky et al. 1995), we employed RT-PCR to check the expression of $A T M$ in the MEFs derived from day-14 $A T M^{+1+}, A T M^{+1-}$, and $A T M^{-1-}$ embryos. In the PCR assays, primers 1 and 2 were used to detect the coding region that was disrupted directly by the PGK-neo ${ }^{\mathrm{r}}$ gene; primers 3 and 4 were outside the targeting construct and used to amplify a larger coding region containing the disrupted exons (Fig. 1A). Using both sets of primers, no expression of the ATM mRNA could be detected in the $A T M^{-1-}$ MEFs (Fig. 1E), indicating that the expression of the ATM kinase domain had been disrupted. Because the ATM kinase domain appears to be essential for the function of ATM, this targeted mutation should destroy the production of a functional ATM.

\section{$\mathrm{ATM}^{-1-} E S$ cells are hypersensitive to $\gamma$-irradiation}

Taking advantage of the capability of ES cells to grow clonally, we established a clonogenic survival assay to examine the sensitivity of $A T M^{-/-}$ES cells to $\gamma$-irradiation. Consistent with cellular hypersensitivity of AT cells, the $A T M^{-1-}$ ES cells are also much more sensitive to the $\gamma$-irradiation than $A T M^{+/+}$and $A T M^{+/-}$ES cells (Fig. 2).

\section{Cell-cycle arrest following irradiation}

In response to DNA damage caused by agents such as $\gamma$ - or UV irradiation, mammalian cells undergo cellcycle $G_{1}$ arrest (Kastan et al. 1992; Lu and Lane 1993). However, inhibition of cell-cycle progression by $\gamma$-irradiation is reduced in cells derived from $\mathrm{AT}$ patients

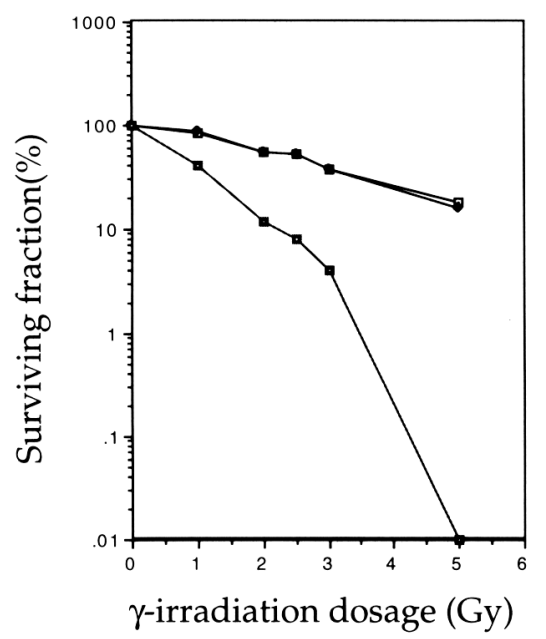

Figure 2. Clonogenic survival of $A T M^{+1+}(0), A T M^{+1-}(\bullet)$, and $A T M^{-1-}(\mathbf{D})$ ES cells following exposure to graded doses of $\gamma$-irradiation. For each irradiation dosage, colonies from duplicated wells were counted. The genotypes are indicated in the figure. Consistent results were obtained from two sets of independently produced $A T M^{+1-}$ and $A T M^{-1-}$ ES cells.
(Meyn 1995). Therefore, we examined the ability of $A T M^{+/+}, A T M^{+/-}$, and $A T M^{-1-}$ MEFs to arrest cell cycle at $\mathrm{G}_{1}$ following $\gamma$-irradiation or UV irradiation using a protocol originally developed by others (Kastan et al. 1991, 1992, Kuerbitz et al 1992). The cells were asynchronously growing at the time of irradiation and their cell-cycle position was assayed using the fluorescenceactivated cell analyzer to measure DNA content and bromodeoxyuridine (BrdU) incorporation during a pulse label at $14 \mathrm{hr}$ after irradiation. In the absence of irradiation, the $A T M^{-1-}$ and $A T M^{+1-}$ cells had somewhat smaller $\mathrm{S}$-phase fractions than the wild-type cells (Fig. 3A; not shown). In normal cells, there was a $75 \%$ loss of S-phase cells following irradiation of $10 \mathrm{~Gy}$ and an accumulation of cells in $\mathrm{G}_{2} / \mathrm{M}$ and $\mathrm{G}_{1} / \mathrm{G}_{0}$ (Fig. 3A). The $A T M^{-1-}$ MEFs had only about a $40 \%$ loss of S-phase at this dose of irradiation. $G_{2} / M$ phase cells accumulated extensively but there were relatively fewer $G_{1} / G_{0}$ cells (Fig. $3 \mathrm{~A}, \mathrm{~B})$. The effects on $\mathrm{S}$-phase cells were dose-dependent (Fig. 3B). The $A T M^{+/-}$MEFs exhibited an intermediate defect in cell-cycle arrest following higher dosages $\geqslant 5$ Gy; Fig. 3A,B), but apparently behaved normally if exposed only to a lower dose (2 Gy; data not shown). In contrast, $A T M^{+1+}, A T M^{+1-}$, and $A T M^{-1-}$ MEFs showed equivalent ability to reduce their $S$-phase fraction following UV-irradiation (Fig. 3B).

To measure the optimal defect of $A T M^{-/-}$MEFs in $\mathrm{G}_{1}$ cell-cycle arrest following $\gamma$-irradiation, we examined the ability of $A T M^{+1+}, A T M^{+1-}$, and $A T M^{-1-}$ MEFs to arrest their cell cycle in $\mathrm{G}_{1}$ phase at different time points following 10-Gy $\gamma$-irradiation. Whereas maximal defects in $G_{1}$ arrest were observed $10 \mathrm{hr}$ following $\gamma$-irradiation, $A T M^{-1-}$ MEFs exhibited defective $\mathrm{G}_{1}$ cellcycle arrest and $A T M^{+1-}$ MEFs showed an intermediate defect at all tested time points following $\gamma$-irradiation (Fig. 3C).

\section{The p53 response to DNA damage}

The p53 protein level is up-regulated transiently after DNA damage and cell-cycle arrest following DNA damage requires an intact p53 gene (Kastan et al. 1992). The role of $\mathrm{p} 53$ may be to activate the expression of a number of genes including p21 CIP1/WAF1 (El-Diery et al. 1993; Xiong et al. 1993; Macleod et al. 1995). To understand the basis of the defective cell-cycle $\mathrm{G}_{1}$ arrest following $\gamma$-irradiation but not UV-irradiation in $A T M^{-1-}$ cells, the protein levels of p53 at different time points following $\gamma$ - or UV irradiation were evaluated by immunoblot analysis of whole-cell extracts. It was confirmed that equivalent amounts of protein were transferred in each lane by staining the nitrocellulose membrane after transfer. One hour following $10 \mathrm{~Gy} \gamma$-irradiation, a significant increase of $\mathrm{p} 53$ protein was seen in both $A T M^{+1+}$ and $A T M^{+1-}$ MEFs (Fig. 4A), although the magnitude of the up-regulation in $A T M^{+1}-$ MEFs appeared to be less than that in $A T M^{+/+}$MEFs. The p53 protein levels decreased at later time points $(2,3,4,5,8 \mathrm{hr})$ following $\gamma$-irradiation in both $A T M^{+1+}$ and $A T M^{+1-}$ MEFs (Fig. 4A, data not shown). In contrast, no increase of $\mathrm{p} 53$ protein level 

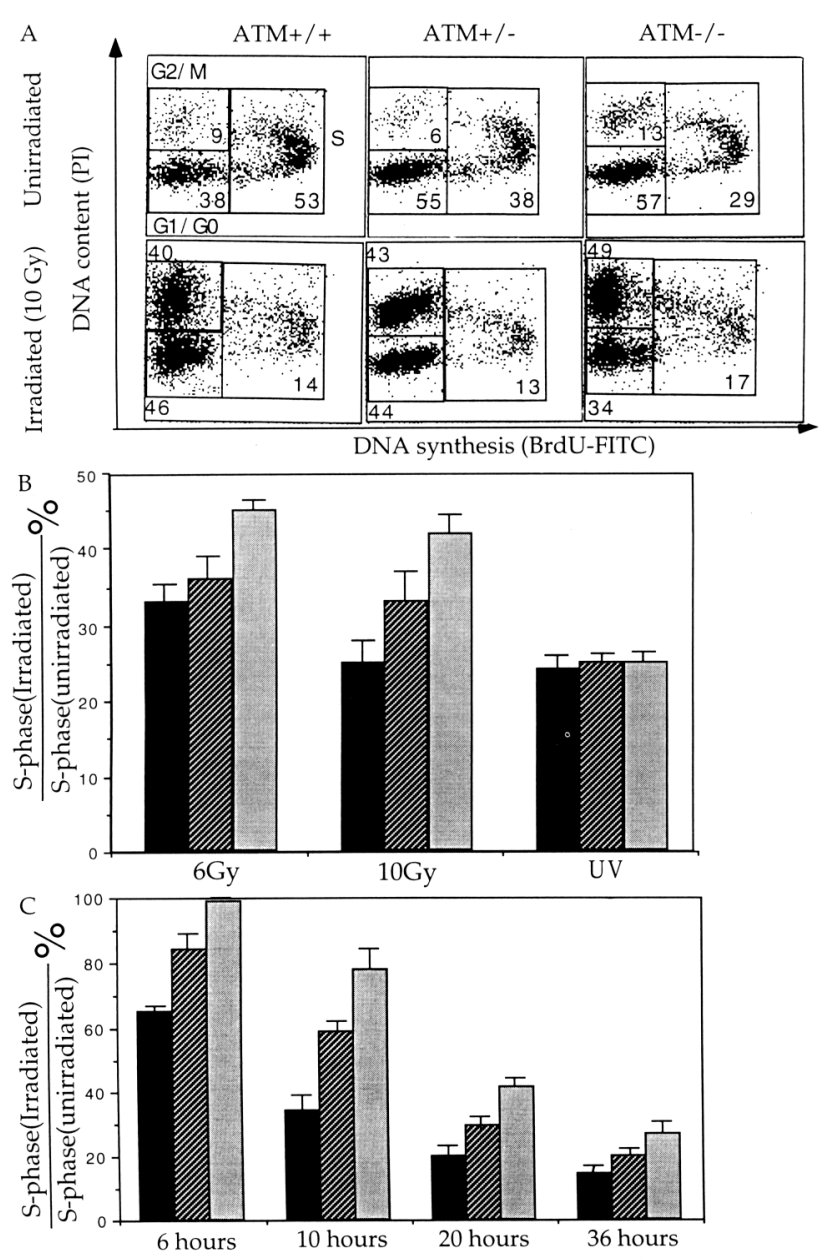

Figure 3. Defective ability of the $A T M^{-1-}$ MEFs to arrest in $\mathrm{G}_{1}$ phase following $\gamma$-irradiation. $\{A \mid$ A FACScan analysis of the untreated and irradiated $A T M^{+1+}, A T M^{+1-}$, and $A T M^{-1}$ MEFs following $10 \mathrm{~Gy} \gamma$-irradiation. DNA synthesis is revealed by FITC-conjugated anti-BrdU antibody and the DNA content is revealed by propidium iodide (PI) staining. Boxes representing cells in $G_{1}, S$, and $G_{2} / M$ phases as well as the percentage of total cells are indicated. We have not observed consistent difference between the number of S-phase cells of $A T M^{+1+}$ and $A T M^{+1-}$ MEFs. (B) Quantitative analysis of the number of cells in $S$ phase following $\gamma$-irradiation versus the number of cells in $S$ phase in an untreated control. (Solid bar) $A T M^{+/+}$; (hatched bar) $A T M^{+1-}$; (gray bar) $A T M^{-1-}$. Three independent experiments were performed for $\gamma$-irradiation at each dosage and two for UV-irradiation at a dosage of $60 \mathrm{~J} / \mathrm{M}^{2}$. The mean value is presented with error bars showing standard derivation. Consistent results were obtained from independently derived MEFs. (C) Quantitative analysis of the number of cells in S phase following $\gamma$-irradiation versus the number of cells in $S$ phase in an untreated control 6, 10, 20,36 hr following $10 \mathrm{~Gy} \gamma$-irradiation. Bars as in $B$. Three independent experiments were performed and mean value is presented with error bars showing standard deviation.

was observed in $A T M^{-1-}$ MEFs $1 \mathrm{hr}$ after $\gamma$-irradiation and only a small increase of p53 protein level was detected at 3 or $4 \mathrm{hr}$ but not at 2, 5, $8 \mathrm{hr}$ following irradi- ation (Fig. 4A; data not shown). Therefore, the p53 response to $\gamma$-irradiation was defective in $A T M^{-1-}$ cells.

Based on the reported kinetics of the p53 response to UV-irradiation in mouse cells ( $\mathrm{Lu}$ and Lane 1993), we analyzed the p53 response in MEFs $14 \mathrm{hr}$ following UV irradiation (Fig. 4B; data not shown). A similar up-regulation of p53 protein level was observed in MEFs of all genotypes (Fig. 4B), indicating that the p53 response to UV irradiation is normal in $A T M^{-1-}$ MEFs.

\section{p21 expression in MEFs}

We also analyzed the p21 protein levels in $A T M^{+1+}$, $A T M^{+1-}$, and $A T M^{-1-}$ MEFs. The specificity of the polyclonal anti-p21 antibody we used has been verified previously (Deng et al. 1995). A considerably higher level of 221 protein was detected in both proliferating and resting $A T M^{-1-}$ MEFs (Fig. $4 \mathrm{C}$ ). In addition, analysis of the $\mathrm{p} 21$ protein level at different time points following serum stimulation of synchronously growth-arrested cells also indicated higher levels of $\mathrm{p} 21$ protein at all time points in $A T M^{-1-}$ MEFs (Fig. 4D). p21 protein lev-

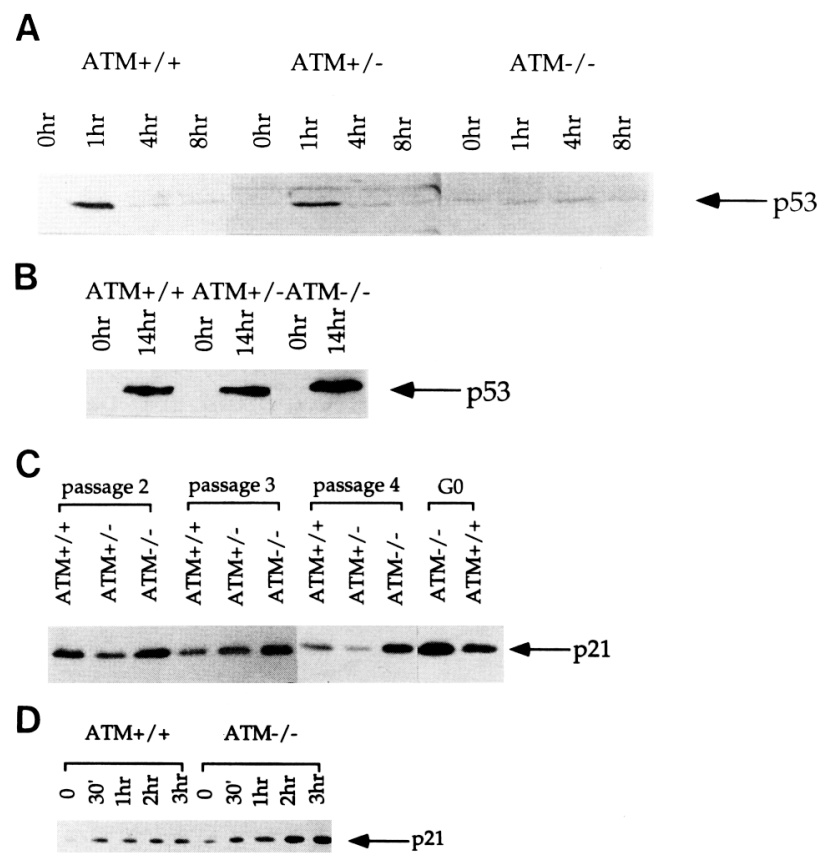

Figure 4. The p53 response to radiation and $\mathrm{p} 21$ protein levels in $A T M^{+1+}, A T M^{+1-}$, and $A T M^{-1-}$ MEFs. $(A)$ The protein levels of p53 at $0,1,4,8 \mathrm{hr}$ following 10 -Gy $\gamma$-irradiation. The lanes are labeled on the top. p53 is indicated with arrowheads. (B) The protein levels of p53 at 0 and $14 \mathrm{hr}$ following $60 \mathrm{~J} / \mathrm{m}^{2}$ UV-irradiation. The lanes are labeled at the top and protein indicated with arrowheads. (C) The p21 protein level in proliferating and resting MEFs. Proliferating MEFs of various passage number were harvested and MEFs resting at $\mathrm{G}_{0}$ were obtained by serum starvation for $96 \mathrm{hr}$. The genotypes and passage numbers are shown on the top and $\mathrm{p} 21$ is indicated with an arrowhead. $(D)$ Protein levels of $\mathrm{p} 21$ at different time points after serum stimulation of $G_{0}$ MEFs. The time points and genotypes are shown on the top and p21 is indicated with arrowheads. 
els in cells derived from AT patients have been examined (Canman et al. 1994). However, no difference was detected between AT cells and cells derived from normal individuals. This could be attributable to a difference between human and mouse cells or the fact that the AT cells used in these studies were immortalized and EBVimmortalization may mask this p21 effect.

\section{$\gamma$-irradiation-induced apoptosis of thymocytes in vivo}

Because $\gamma$-irradiation-induced apoptosis of immature thymocytes is mediated by p 53 (Clarke et al. 1993; Lowe et al. 1993) and the p53 response to $\gamma$-irradiation is defective in $A T M^{-1-}$ MEFs (Fig. 4A), we examined the apoptotic response of $A T M^{+1-}$ and $A T M^{-1-}$ thymocytes to in vivo $\gamma$-irradiation. T-cell development in the thymus of both $A T M^{+1-}$ and $A T M^{-1-}$ mice is defective and will be described in detail elsewhere (Fig. 5A; Xu et al., this issue). As expected, the immature $\mathrm{CD} 4{ }^{+} \mathrm{CD} 8{ }^{+}$thymocytes, which are most susceptible to apoptosis, essentially disappear in the thymus of normal mice $48 \mathrm{hr}$ after exposure to 5-Gy $\gamma$-irradiation (Smith et al. 1989; Clarke et al. 1993; Lowe et al. 1993; Fig. 5A-C). Similar to $A T M^{+1+}$ mice, total thymocyte number is also reduced significantly in $A T M^{-1-}$ mice $48 \mathrm{hr}$ after exposure to $\gamma$-irradiation, indicating that $A T M^{-1-}$ thymocytes are also sensitive to $\gamma$-irradiation (Fig. $5 \mathrm{C}$ ). However, compared with that of $A T M^{+/+}$mice, the much higher percentage of immature thymocytes surviving the effect of $\gamma$-irradiation in $A T M^{-1-}$ mice indicates that $A T M^{-1-}$ immature thymocytes are more resistant to the effects of $\gamma$-irradiation than normal immature thymocytes, implying that $\mathrm{p} 53$-mediated apoptosis following $\gamma$-irradiation is defective in $A T M^{-1-}$ thymocytes (Fig. 5A-C). $A T M^{+/-}$thymocytes displayed an intermediate resistance to $\gamma$-irradiation (Fig. 5A,B).

\section{Impaired proliferation of $\mathrm{ATM}^{-1-}$ MEFs in cultures}

Fibroblasts derived from AT patients display a premature senescence (Shiloh et al. 1985). Therefore, we examined the growth properties of $A T M^{+/+}, A T M^{+/-}$, and $A T M^{-1-}$ MEFs. Irrespective of their passage numbers, $A T M^{-1-}$ MEFs proliferated more slowly than $A T M^{+1+}$ and $A T M^{+1-}$ MEFs $($ Fig. 6A,B). In addition, and in contrast to $553^{-/-}$MEFs, the saturation density of $A T M^{-1}$ - MEFs is only about half that of $A T M^{+1-}$ and $A T M^{+1}$ + MEFs (Fig. 6A,B; Deng et al. 1995). After passage 6, the $A T M^{-1-}$ MEFs essentially became senescent, whereas the $A T M^{+1-}$ and $A T M^{+1+}$ MEFs continued to proliferate (Fig. $6 \mathrm{C}$ ).

\section{$G_{1} / S$ progression in the cell cycle of $\mathrm{ATM}^{-1-} M E F s$}

To examine the defects in cellular growth involved in the slow proliferation and ultimate senescence of the mutant fibroblasts, we asked how efficiently the cells came into $\mathrm{S}$ phase after serum stimulation. $A T M^{+/+}$, $A T M^{+1-}$, and $A T M^{-1-}$ MEFs of passage 3 synchronized at $G_{0}$ by serum starvation were released into medium
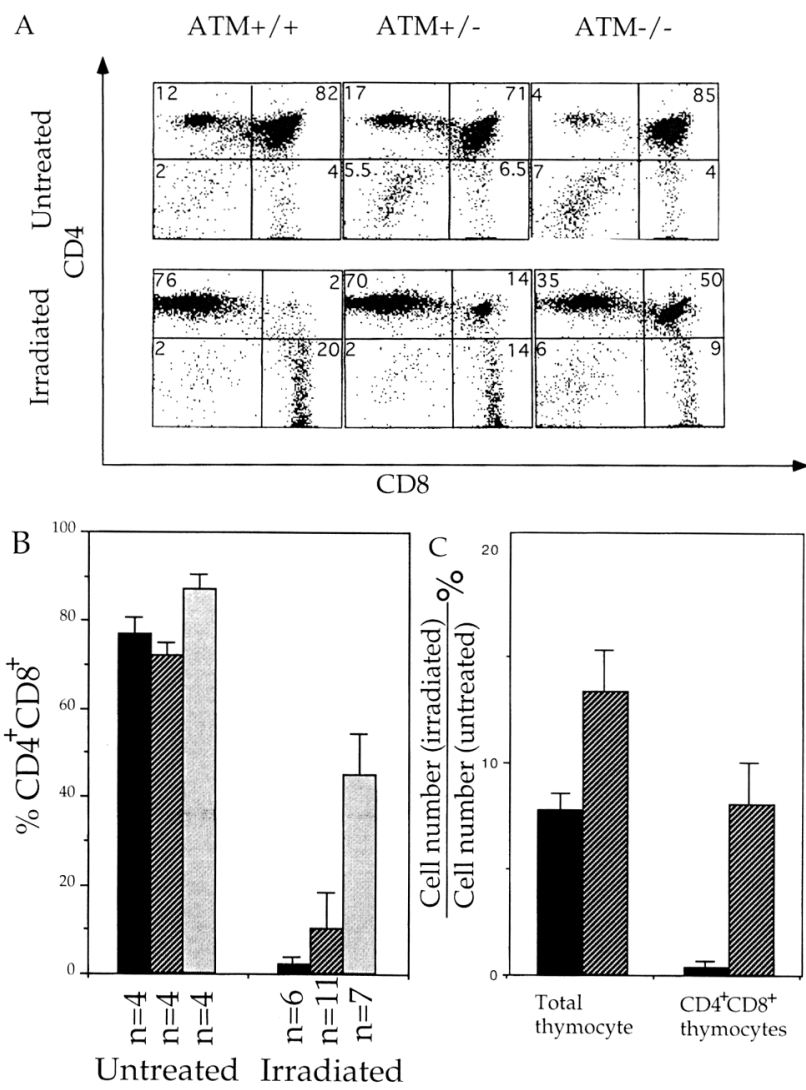

Figure 5. $\gamma$-irradiation-induced apoptosis of mouse thymocytes. (A) Thymocytes were derived from $A T M^{+1+}, A T M^{+1-}$, and $A T M^{-1-}$ mice either exposed to $\gamma$-irradiation $15 \mathrm{~Gy}$; bottom) or without any treatment (top) and analyzed for the expression of $\mathrm{CD} 4$ or $\mathrm{CD} 8$ surface markers. The percentage of subpopulations of thymocytes is indicated. $(B)$ Mean percentage of immature $\mathrm{CD} 4{ }^{+} \mathrm{CD} 8{ }^{+}$thymocytes in $A T M^{+1+}$ (solid bar), $A T M^{+1-}$ (hatched bar), and $A T M^{-1-}$ (gray bar) mice $48 \mathrm{hr}$ after exposure to 5-Gy $\gamma$-irradiation or no treatment. $\mathrm{n}$ represents the number of mice analyzed. $(C)$ Thymocyte reduction following $\gamma$-irradiation. Thymocytes were recovered from $A T M^{+/+}$(solid bar) and $A T M^{-1-}$ (hatched bar) mice $48 \mathrm{hr}$ after exposure to 5Gy $\gamma$-irradiation. Thymocytes were also recovered from littermates or same-aged mice without irradiation treatment. Five sets of irradiated and untreated mice of each genotype were analyzed and percentile ratio of thymocyte number derived from irradiated versus untreated mice is presented with error bars showing standard deviation.

containing $10 \%$ fetal calf serum and 24 or $72 \mathrm{hr}$ later the percentage of cells in $\mathrm{S}$ phase was determined. Compared with $A T M^{+/+}$and $A T M^{+/-}$MEFs, a considerably lower percentage of $A T M^{-1-}$ cells had entered the $\mathrm{S}$ phase $24 \mathrm{hr}$ after serum stimulation (Fig. 7A,B). However, $>90 \%$ of $A T M^{+1+}$ and $A T M^{-1-}$ MEFs had entered the $\mathrm{S}$ phase by $72 \mathrm{hr}$ (data not shown). Therefore, $A T M^{-1-}$ MEFs have a defective ability to enter $\mathrm{S}$ phase, probably accounting for their slower growth.

\section{Discussion}

Previous work had demonstrated a number of defects in 


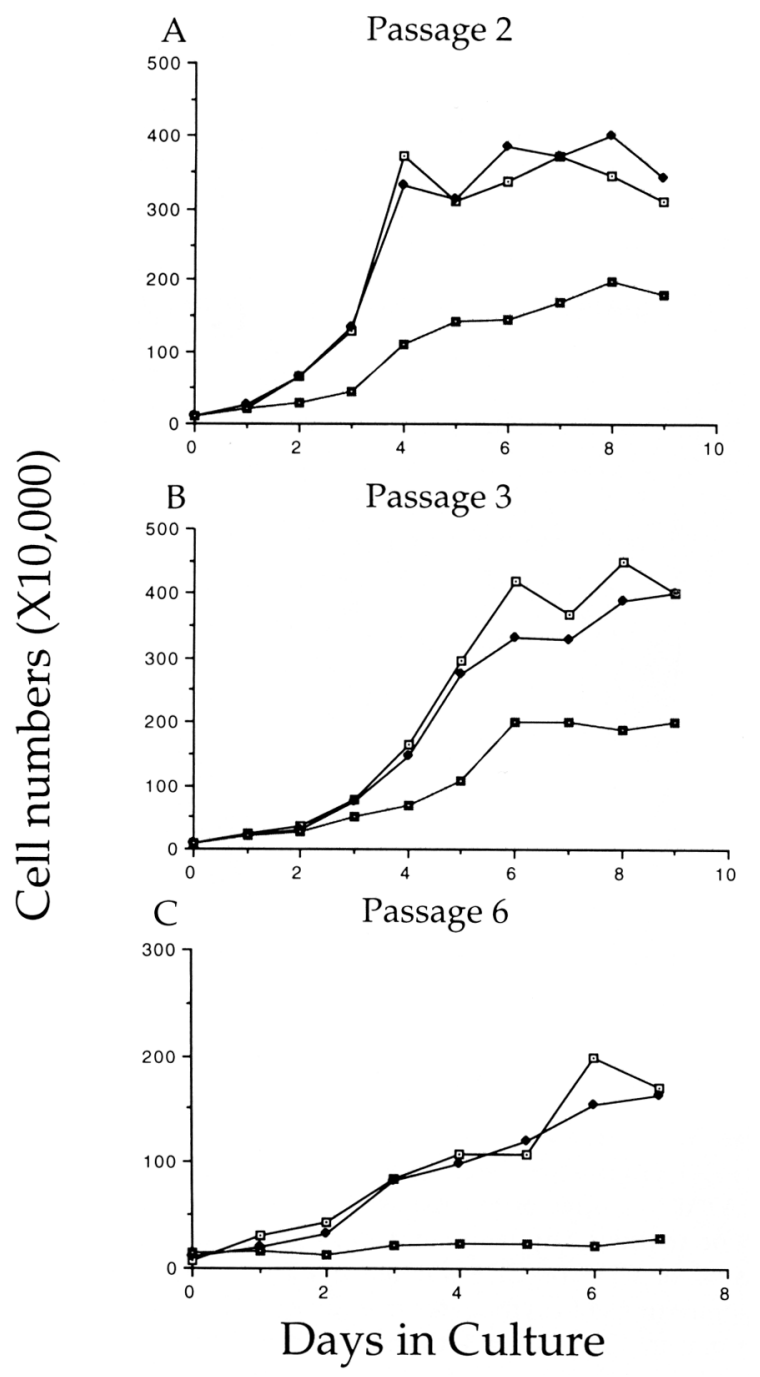

Figure 6. Proliferation curves and saturation density of $A T M^{+1+}(\bullet), A T M^{+1-}(\bullet)$, and $A T M^{-1-}(\mathbf{D})$ MEFs at $(A)$ passage $2,(B)$ passage 3 , and $(C)$ passage 6 . The cell number represents the average of the three plates counted at each time point. The genotypes and passage numbers are indicated in the figure.

$A T M^{-1-}$ human cells derived from patients, but there was disagreement in the literature about their nature, probably as a consequence of the genetic heterogeneity inherent in human studies. In particular, it is not clear that all human ATM alleles give the same phenotype. Using $A T M^{-1}$ cells derived from mice with a disrupted $A T M$ gene, we could confirm certain previous studies and provide a clear picture of two types of defects in the cells, one for the response to ionizing radiation and the other in normal growth control. As significantly, we could demonstrate a series of defects in $A T M^{+1-}$ cells that might explain an increased tendency to carcinogenesis in heterozygous individuals.

Studying the response of cells to $\gamma$-irradiation, we found that-consistent with previous studies of fibroblasts derived from AT patients (Meyn 1995)-the
$A T M^{-1-}$ cells do not arrest as effectively as wild-type cells. They maintain more S-phase cells after irradiation, indicating a lack of an effective block at the $\mathrm{G}_{1} / \mathrm{S}$ border. They were not defective in their response to UV irradiation. Thus, ATM behaves as a checkpoint controller for cells that have been exposed to ionizing radiation, perhaps indicating that the protein is involved in sensing the DNA strand breaks caused by the irradiation. An important conclusion from these studies is that in the absence of ATM function, $\gamma$-irradiation does not induce p53 effectively. This indicates that p53 is downstream of ATM.

Consistent with studies of human AT cells, ES cells that are $A T M^{-1-}$ are more sensitive to $\gamma$-irradiation than normal ES cells. A defective ability of AT cells to cell-cycle arrest following DNA damage has been suggested previously to contribute to the hypersensitivity of AT cells to ionizing radiation and the high frequency of tumorgenesis in AT patients (Lehmann 1982; Shiloh et al. 1985).

Paradoxically, $A T M^{-1-} \mathrm{CD} 4{ }^{+} \mathrm{CD} 8{ }^{+}$thymocytes that have been irradiated in situ are more resistant to $\gamma$-irradiation than their wild-type counterparts but this probably indicates that ATM is involved in signaling an apoptotic response in some cells and a growth arrest re-
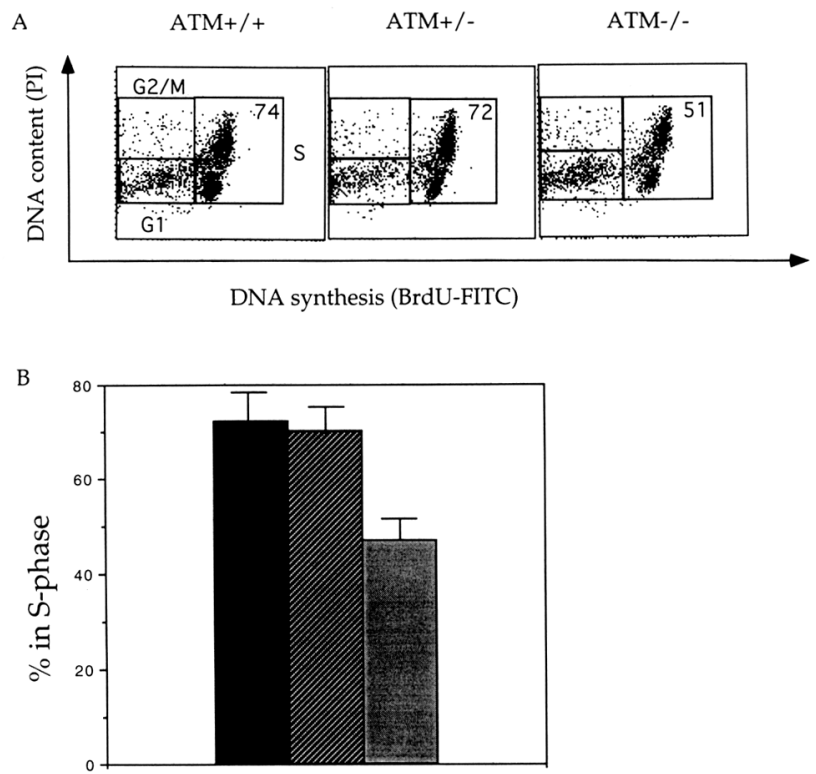

Figure 7. S-phase entry following serum stimulation of synchronized $A T M^{+1+}, A T M^{+1-}$, and $A T M^{-1-}$ MEFs. (A) FACScan analysis of synchronized MEFs after serum stimulation. Serum-starved $A T M^{+1+}, A T M^{+1-}$, and $A T M^{-1-}$ MEFs were released into DMEM containing $10 \%$ FBS for $24 \mathrm{hr}$ and harvested. The S-phase cells $\left(\mathrm{BrdU}^{+}\right)$are revealed with FITCconjugated anti-BrdU and DNA content is revealed with propidium iodide. Boxes representing cells in $\mathrm{G}_{0} / \mathrm{G}_{1}, \mathrm{~S}$, and $\mathrm{G}_{2} / \mathrm{M}$ phases and percentages of cells in $\mathrm{S}$ phase are indicated. $(B \mid$ Quantitative analysis of the percentage of S-phase cells after serum stimulation of synchronized $A T M^{+1+}$ (solid bar), $A T M^{+1-}$ (hatched bar), and $A T M^{-1-}$ (gray bar) MEFs. Three independent experiments were carried out and the mean value with error bars are presented. 
sponse in others, just as seen for p53 signaling/Clarke et al. 1993; Lowe et al. 1993).

ATM appears to play a key role in normal control of fibroblast growth. MEFs from $A T M^{-1-}$ mice showed three defects in in vitro growth: a lower saturation density, slow passage through the $G_{1} / S$ border after serum stimulation, and a more rapid senescence. Fibroblasts derived from AT patients (Shiloh et al. 1985) display an apparent premature senescence. In addition, $A T M^{-/-}$ mouse cells also showed a higher than normal constitutive level of p21 at all times. What causes the increased p21 is not clear, and whether it is the cause of the various effects on cell growth must be tested, but the correlation of increased p21 and senescence has been noted before (Halevy et al. 1995; Nakanishi et al. 1995; Parker et al. 1995).

$A T M^{+1-}$ cells showed partial defects in certain parameters we measured but not others. In particular, they were unaltered in their sensitivity to $\gamma$-irradiation, but that was only measured in ES cells at a low radiation dose $(\leqslant 5 \mathrm{~Gy})$; they showed a partial defect in cell-cycle arrest at high doses of ionizing radiation; their radiationinduced p53 response was lower than wild-type; they showed some resistance to thymocyte death; but their in vitro growth parameters were unaffected. The defects are probably not caused by the generation of a dominant negative gene product from the mutant ATM allele, because humans heterozygous for different mutations of the ATM gene, including a deletion of the whole ATM locus or missense mutations in the kinase domain, share similar intermediate cellular defects (Lehmann 1982; Shiloh et al. 1985). Heterozygous humans have a somewhat increased cancer rate but none of the other symptoms of AT (Swift et al. 1987, 1991). The defects in radiation response of the heterozygous cells suggest that the increased cancer risk could be attributable to the incomplete cell-cycle arrest and a decreased apoptotic response following DNA damage. The lack of changed cell-cycle parameters in $A T M^{+/-}$cells suggests that normal cell growth may be less sensitive to the level of ATM than the checkpoint functions and the multiorgan defects such as growth retardation, premature aging, and thymus degeneration in AT patients (Lehman et al. 1982) could be more a consequence of the cell growth defect in $A T M^{-1-}$ cells than the lack of radiation response. The cancer risk in AT heterozygotes, however, could be a direct reflection of the poor radiation response in the heterozygous cells.

\section{ATM regulates the $\mathrm{p} 53$ response to ionizing radiation}

It has been shown that the cell-cycle arrest in $G_{1}$ following DNA damage is mediated by $\mathrm{p} 53$ and that DNA damages lead to a rapid and transient increase of $\mathrm{p} 53$ protein level (Kastan et al. 1992; Kuerbitz et al. 1992; Lu and Lane 1993). Previous studies to evaluate the p53 response to $\gamma$-irradiation in AT cells have yielded conflicting results (Kastan et al. 1992; Lu and Lane 1993). In general agreement with previous reports by Kastan et al. (1992) and Khanna et al. (1993), we found that the p53 response to $\gamma$-irradiation in $A T M^{-1-}$ MEFs is substantially defective, indicating that ATM plays a significant role in signaling the p53 response following ionizing irradiation. The delayed kinetics of the p53 response to $\gamma$-irradiation we observed in $A T M^{-1-}$ MEFs has also been reported by Lu and Lane (1993) in human AT fibroblasts. However, the greatly reduced p 53 response in $A T M^{-1-}$ cells was not observed by $\mathrm{Lu}$ and Lane.

$\gamma$-irradiation-induced apoptosis of thymocytes is mediated by p53 (Clarke et al. 1993; Lowe et al. 1993). Therefore, the finding that $A T M^{-1-}$ thymocytes, although still sensitive to $\gamma$-irradiation, are more resistant to apoptosis induced by $\gamma$-irradiation than normal immature thymocytes suggests that the p53 response to DNA damage also may be defective in $A T M^{-1-}$ thymocytes, supporting further the notion that ATM is responsible for signaling the p53 response to DNA-strand-break damage. The resistance of these ATM mutant thymocytes to p53-mediated apoptosis following DNA damage would allow thymocytes harboring damaged DNA to survive and undergo selection for the mutated cells that are neoplastic. This might explain why the predominant tumors found in AT patients are of lymphoid origin (Lehmann 1982). In fact, a greatly increased frequency of thymic lymphomas is now appearing in our $A T M^{-1-}$ mice and these tumors are of $\mathrm{CD} 4{ }^{+} \mathrm{CD} 8{ }^{+}$origin (Xu et al., this issue).

Synthesis of p53 protein is regulated negatively by wild-type p53 that binds to the $5^{\prime}$ untranslated region and inhibits the translation of its own mRNA (Mosner et al. 1995). The rapid and transient up-regulation of p53 following DNA damage is mediated through a post-transcriptional mechanism perhaps involving protein stabilization (Kastan et al. 1992; Mosner et al. 1995). In this context, ATM may function by sensing DNA damage and signaling events like relief of the translational inhibition or stabilization of p53. In addition, ATM may carry out its function by directly phosphorylating $\mathrm{p} 53$, as suggested by the observation that DNA-PK, a relative of ATM, can phosphorylate p53 in vitro (Hartley et al. 1995).

After this paper was submitted, Barlow et al. (1996) published their description of independently generated ATM mutant mice. Fibroblasts derived from their ATM mutant mice are also defective in both cell-cycle checkpoint control following $\gamma$-irradiation and cellular proliferation.

\section{Materials and methods}

Cloning of the human ATM CDNA fragment by PCR

A 516-bp cDNA fragment encoding the conserved kinase sequence was amplified from a human B cell cDNA library (gift from S. Elledge, Baylor College of Medicine, Houston, TX) by PCR using primers specific for the human ATM gene (Hunter 1995; Savitsky et al. 1995). The PCR reaction was done in a final volume of $100 \mu \mathrm{l}$ containing $2 \mu \mathrm{g}$ of cDNA, $150 \mathrm{ng}$ of each primer, $1 \times$ PCR buffer (Boehringer Mannheim), $0.2 \mathrm{mM} \mathrm{dNTP,}$ and 5 units of Taq polymerase (Boehringer Mannheim). PCR was run for 35 cycles, each consisting of $1 \mathrm{~min}$ at $94^{\circ} \mathrm{C}, 1.5 \mathrm{~min}$ 
at $62^{\circ} \mathrm{C}$ and $1 \mathrm{~min}$ at $72^{\circ} \mathrm{C}$. The final reaction step was followed with an extension at $72^{\circ} \mathrm{C}$ for $10 \mathrm{~min}$. The PCR product was cloned into the BamHI site of pBluescript SK and verified by DNA sequencing. The sequences of the primers used to amplify the ATM cDNA fragment were as follows: $5^{\prime}$-TGCTCATAAAGGATCCAGGCCAAATGATTT-3'; 5'-AAGAGTGGATCCTATAGAACCTCTACAATG-3'.

\section{Targeting construct to disrupt the ATM gene in ES cells}

The cloned ATM cDNA fragment was used as a probe to isolate several murine ATM genomic fragments from a mouse 129 genomic library (Strategene) as described previously (Xu et al. 1996b). The exon-intron structure was characterized by restriction mapping, Southern blotting analysis, and DNA sequencing. The mouse protein sequence encoded by the two exons in the genomic fragment is essentially identical to corresponding human protein sequence (Fig. 1A; data not shown). The targeting construct was designed to insert the PGK-neo ${ }^{\mathrm{r}}$ gene into the exon encoding the kinase-conserved sequence and simultaneously to delete the adjacent exon (Fig. 1A,B). The targeting construct was generated by inserting a $1.2-\mathrm{kb}$ Sall-StyI ATM genomic fragment into the $X b a I$ site $5^{\prime}$ of the PGK-neo ${ }^{\mathrm{r}}$ gene and a $8.5-\mathrm{kb} X$ hol $A T M$ genomic fragment into the Xhol site $3^{\prime}$ of the PGK-neo ${ }^{\mathrm{r}}$ gene. A 12-kb SalI-AflII DNA fragment was excised out of the targeting construct plasmid and electroporated into J1 ES cells (Fig. 1A,B).

Generation of $\mathrm{ATM}^{+/-}$and $\mathrm{ATM}^{-1-}$ ES cells and germ-line transmitting chimeric mice

J1 ES cells were cultured, electroporated, and selected with G418 (300 $\mu \mathrm{g} / \mathrm{ml})$ as described (Li et al. 1992). Homologous recombination events were screened by Southern blotting analysis with $\mathrm{BamHI}$ digestion and hybridization to the $1.6-\mathrm{kb}$ probe $\mathrm{A}$, and subsequently confirmed with $\mathrm{BamHI}$ digestion and hybridization to the $1.2 \mathrm{~kb}$ probe $\mathrm{B}$ (Fig. 1A). To generate the $A T M^{-1-}$ ES cells, $A T M^{+1-}$ ES cells were cultured under increasing concentrations of G418 as described previously (Mortensen et al. 1992; Xu et al. 1996b). Seven ATM ${ }^{+1-}$ ES celllines were microinjected into $\mathrm{C} 57 \mathrm{BL} / 6$ blastocysts that were implanted subsequently into the uteri of Balb/c foster mothers. Male chimeric mice generated from $6 A T M^{+1-}$ ES clones transmitted the ATM mutation into germ-line. The presence of the ATM mutant allele in the F1 animals was confirmed by Southern blotting. $A T M^{+1-} \mathrm{Fl}$ animals were bred together to generate $A T M^{-1-}$ mice.

\section{Generation and culture of primary MEFs}

Primary MEFs were derived from day $14 \mathrm{ATM}^{+1+}, \mathrm{ATM}^{+/-}$, and $A T M^{-1-}$ embryos as described (Robertson 1987). Genotypes of each MEF culture was verified by Southern blotting. Cells were cultured in Dulbecco's modified Eagle's medium (DMEM) supplemented with $10 \%$ fetal calf serum, $5 \mathrm{~mm}$ glutamine, $50 \mu \mathrm{M} \beta$-mecaptoethanol, penicillin, and streptomycin at $37^{\circ} \mathrm{C}$ with $5 \% \mathrm{CO}_{2}$.

\section{Analysis of the ATM mRNA expression with RT-PCR}

Total RNA was isolated from $A T M^{+/+}, A T M^{+/-}$, and $A T M^{-1-}$ MEFs using TRI REAGENT following the manufacturer's instruction (Molecular Research Center, Inc.). RT-PCR was carried out as described (Beg et al. 1995). Briefly, $3 \mu \mathrm{g}$ of total RNA was reverse-transcribed into cDNA and $1 \mu l$ of the synthesized cDNA was used in the PCR reaction using three sets of primers: primers 1 and 2, primers 3 and 4, or primers specific for $\beta$-actin. The PCR reaction was done in a final volume of $50 \mu \mathrm{l}$ containing $150 \mathrm{ng}$ of each primer, $1 \times$ PCR buffer $0.2 \mathrm{mM}$ dNTP, and 2 units of Taq polymerase. The PCR reaction went for 30 cycles, each consisting of $1 \mathrm{~min}$ at $94^{\circ} \mathrm{C}, 1.5 \mathrm{~min}$ at $60^{\circ} \mathrm{C}$, and $1.5 \mathrm{~min}$ at $72^{\circ} \mathrm{C}$. The final reaction step was followed by an extension at $72^{\circ} \mathrm{C}$ for $10 \mathrm{~min}$. Half of the reaction was analyzed on a $1.2 \%$ agarose gel. The sequences of the primers used were as follows: primer 1: 5'-GCTCGTTTATCAAGATATTCTGT-3'; primer 2: 5'-AAGTCTTTTGAAGAGAAATATGA-3'; primer 3: 5'-AAGAGTGGATCCTATAGAACCTCTA CAATG-3'; primer 4: 5'-TGCTCATAAAGGATCCAGGCCAAATGATTT-3'. Sequences for $\beta$-actin primers have been described previously (Beg et al. 1995).

\section{Clonogenic survival assay for $\gamma$-irradiation}

$A T M^{+1+}, A T M^{+1-}$, and $A T M^{-1-}$ ES cells were plated on the MEF feeder layer in a series of six-well plates at a density of $1 \times$ $10^{3} /$ well. Twenty hours after plating, ES cells were exposed to graded doses of $\gamma$-irradiation with a ${ }^{137} \mathrm{Cs}$ source at a rate of 0.86 $\mathrm{Gy} / \mathrm{min}$ ( $1 \mathrm{~Gy}=100 \mathrm{rads})$. The irradiated ES cells were maintained by changing their medium once every 2 days. The surviving ES colonies in each well were counted after 7-8 days of culture.

\section{Irradiation treatment of MEFs and cell-cycle analysis}

Asynchronous MEFs were plated at a density of $0.5 \times 10^{5}$ to $0.8 \times 10^{5}$ cells per $10-\mathrm{cm}$ plate and irradiated within $24 \mathrm{hr}$ after plating. Fourteen hours after irradiation, cells were pulsed with $10 \mu \mathrm{M} \mathrm{BrdU}$ for $4 \mathrm{hr}$, harvested, and fixed in $70 \%$ ethanol. For $\gamma$-irradiation, MEFs were irradiated in the culture medium with a ${ }^{60} \mathrm{Co}$ source at a rate of $4.3 \mathrm{~Gy} / \mathrm{min}$. For UV irradiation, culture medium and plate cover were removed before MEFs were irradiated with a UV Stratelinker (Strategene).

For the cell-cycle analysis, DNA synthesis and DNA content were analyzed using flow cytometry as described (Kastan et al. 1992). Briefly, BrdU-labeled cells fixed in $70 \%$ ethanol were treated with $1 \mathrm{~N} \mathrm{HCl}$ containing $0.7 \%$ Triton $\mathrm{X}-100$ for $10 \mathrm{~min}$ on ice. Subsequently, cells were resuspended in $30 \mathrm{~mm} \mathrm{HCl}$, heated at $100^{\circ} \mathrm{C}$ for $10 \mathrm{~min}$, and transferred back on ice immediately. Cells were incubated with fluorescein isothiocyanateconjugated anti-BrdU antibodies (Southern Biotech., Inc.), followed by staining with propidium iodide $(250 \mu \mathrm{g} / \mathrm{ml})$ containing RNase $(10 \mu \mathrm{g} / \mathrm{ml})$ overnight. The stained cells were analyzed with a FACscan (Becton-Dickinson) using a CellQuest program as described (Brugarolas et al. 1995).

\section{Protein analysis and antibodies}

Immunoblot assays were performed as described (Kastan et al. 1992). Protein extract from $5 \times 10^{5}$ cells was loaded into each lane, separated by $12 \%$ SDS-PAGE and transferred to nitrocellulose. After transfer, the membrane was reversibly stained with Ponceau Red to verify the equivalent amount of protein in each lane. The filter was probed with either a monoclonal antip53 antibody (P240) or polyclonal anti-p21 antibody obtained from Santa Cruz Biochemicals. The filter was subsequently incubated with horseradish peroxidase-conjugated secondary antibody and developed with enhanced chemiluminescence (ECL) (Amersham).

\section{Radiation-induced thymocyte apoptosis in vivo}

Irradiation treatment of animals and analysis of thymocytes were performed as described (Lowe et al. 1993). Briefly, thymo- 
cytes were recovered from mice of all genotypes $48 \mathrm{hr}$ after exposure to $\gamma$-irradiation $(5 \mathrm{~Gy})$ and stained with PE-conjugated anti-CD4 antibody and FITC-conjugated anti-CD8 antibody (both from Pharmingen). As controls, thymocytes from mice without any treatment were also analyzed. Stained cells were analyzed with a FACscan (Becton-Dickinson) using a CellQuest program.

Proliferation assay and analysis of $G_{1} / S$ transition during the cell-cycle progression

Cell proliferation and saturation density assays were performed essentially as described (Deng et al. 1995), except that three plates were counted at each time point. To synchronize cells at $\mathrm{G}_{0}, 70-80 \%$ confluent asynchronous culture was washed with PBS and then placed in DMEM containing $0.1 \%$ FBS for $96 \mathrm{hr}$. Cells were harvested and released into DMEM containing $10 \%$ FBS and $10 \mu \mathrm{M}$ BrdU for 24 or $72 \mathrm{hr}$ and harvested. Cells in the $S$ phase were analyzed with flow cytometry as described above.

\section{Acknowledgments}

We thank J. Lawitts and the transgenic facility of Beth Israel Hospital for generating chimeric mice, J. Brugarolos for advice on cell-cycle analysis, and A. Beg for critically reading the manuscript. This project was supported by a National Institutes of Health grant to D.B. Y.X. was supported by the Cancer Research Fund of Damon Runyon-Walter Winchell Foundation. D.B. is an American Cancer Society Research Professor.

The publication costs of this article were defrayed in part by payment of page charges. This article must therefore be hereby marked "advertisement" in accordance with 18 USC section 1734 solely to indicate this fact.

\section{References}

Barlow, C., S. Hirotsune, R. Paylor, M. Liyanage, M. Eckhaus, F. Collins, Y. Shiloh, J.N. Crawley, T. Ried, D. Tagle, and A. Wynshaw-Boris. 1996. Atm-deficient mice, a paradigm of ataxia-telangiectasia. Cell 86: 159-171.

Beg, A.A., W.C. Sha, R.T. Bronson, S. Ghosh, and D. Baltimore. 1995. Embryonic lethality and liver degeneration in mice lacking the RelA component of NF-kappa $\beta$. Nature 376: 167-170.

Blunt, T., N.J. Finnie, G.E. Taccioli, G.C. Smith, J. Demengeot, T.M. Gottlieb, R. Mizuta, A.J. Varghese, F.W. Alt, P.A. Jeggo, and S.P. Jackson. 1995. Defective DNA-dependent protein kinase activity is linked to V(D)J recombination and DNA repair defects associated with the murine scid mutation. Cell 80: 813-823.

Brown, E.J., P.A. Beal, C.T. Keith, J. Chen, T.B. Shin, and S.L. Schreiber. 1995. Control of p70 s6 kinase by kinase activity of FRAP in vivo. Nature 377: 441-446.

Brugarolas, J., C. Chandrasekaran, J.I. Gordon, D. Beach, T. Jacks, and G.J. Hannon. 1995. Radiation-induced cell cycle arrest compromised by $\mathrm{p} 21$ deficiency. Nature 377: 552-557.

Canman, C.E., A.C. Wolff, C.Y. Chen, A.J. Fornace, Jr., and M.B. Kastan. 1994. The p53-dependent Gl cell cycle checkpoint pathways and ataxia-telangiectasia. Cancer Res. 54: 5054 5058.

Carpenter, C.L., K.R. Auger, B.C. Duckworth, W.M. Hou, B. Schaffhausen, and L.C. Cantley. 1993. A tightly associated serine/threonine kinase regulates phosphoinositide 3-kinase activity. Mol. Cell. Biol. 13: 1657-1665.

Clarke, A.R., C.A. Purdie, D.J. Harrison, R.G. Morris, C.C. Bird, M.L. Hooper, and A.H. Wylie. 1993. Thymocyte apoptosis induced by p53-dependent and independent pathways. $\mathrm{Na}$ ture 362: 849-852.

Deng, C., P. Zhang, J.W. Harper, S.J. Elledge, and P. Leder. 1995. Mice lacking p21 CIP1/WAF1 undergo normal development, but are defective in Gl checkpoint control. Cell 82: 675684.

Dhand, R., I. Hiles, G. Panayotou, S. Roche, M.J. Fry, I. Gout, N.F. Totty, O. Truong, P. Vicendo, K. Yonezawa, M. Kasuga, S.A. Courtneidge, and M.D. Waterfield. 1994. PI 3-kinase is a dual specificity enzyme: Autoregulation by an intrinsic protein-serine kinase activity. $E M B O$ f. 13: 522-533.

El-Deiry, W.S., T. Tokino, V.E. Velculescu, D.B. Levy, R. Parsons, J.M. Trent, D. Lin, W.E. Mercer, K.W. Kinzler, and B. Vogelstein. 1993. WAF1, a potential mediator of p53 tumor suppression. Cell 75: 817-825.

Greenwell, P.W., S.L. Kronmal, S.E. Porter, J. Gassenhuber, B. Obermaier, and T.D. Petes. 1995. TELl, a gene involved in controlling telomere length in S. cerevisiae, is homologous to the human ataxia telangiectasia gene. Cell 82: 823-829.

Halevy, O., B.G. Novitch, D.B. Spicer, S.X. Skapek, J. Rhee, G.J. Hannon, D. Beach, and A.B. Lassar. 1995. Correlation of terminal cell cycle arrest of skeletal muscle with induction of p21 by MyoD. Science 267: 1018-1021.

Hari, K.L., A. Santerre, J.J. Sekelsky, K.S. McKim, J.B. Boyd, and R.S. Hawley. 1995. The mei-4l gene of D. melanogaster is a structural and functional homolog of the human ataxia telangiectasia gene. Cell 82: 815-821.

Hartley, K.O., D. Gell, G.C. Smith, H. Zhang, N. Divecha, M.A Connelly, A. Admon, S.P. Lees-Miller, C.W. Anderson, and S.P. Jackson. 1995. DNA-dependent protein kinase catalytic subunit: A relative of phosphatidylinositol 3-kinase and the ataxia telangiectasia gene product. Cell 82: 849-856.

Hunter, T. 1995. When is a lipid kinase not a lipid kinase? When it is a protein kinase. Cell 83: 1-4.

Kastan, M.B., O. Onyekwere, D. Sidransky, B. Vogelstein, and R.W. Craig. 1991. Participation of p53 protein in the cellular response to DNA damage. Cancer Res. 51: 6304-6311.

Kastan, M.B., Q. Zhan, W.S. El-Deiry, F. Carrier, T. Jacks, W.V. Walsh, B.S. Plunkett, B. Vogelstein, and A.J. Fornace, Jr. 1992. A mammalian cell cycle checkpoint pathway utilizing p53 and GADD45 is defective in ataxia-telangiectasia. Cell 71: 587-597.

Khanna, K.K. and M.F. Lavin. 1993. Ionizing radiation and UV induction of $\mathrm{p} 53$ protein by different pathways in ataxiatelangiectasia cells. Oncogene 8: 3307-3312.

Kuerbitz, S.J., B.S. Plunkett, W.V. Walsh, and M.B. Kastan. 1992. Wild-type p53 is a cell cycle checkpoint determinant following irradiation. Proc. Natl. Acad. Sci. 89: 7491-7495.

Lehmann, A.R. 1982. Ataxia-Telangiectasia: A cellular and molecular link between cancer, neuropathology and immune deficiency (ed. B.A. Bridges and D.G. Harnden), pp. 83-102. Wiley, Chichester, UK.

Li, E., T.H. Bestor, and R. Jaenisch. 1992. Targeted mutation of the DNA methyltransferase gene results in embryonic lethality. Cell 69: 915-926.

Lowe, S.W., E.M. Schmitt, S.W. Smith, B.A. Osborne, and T. Jacks. 1993. p53 is required for radiation-induced apoptosis in mouse thymocytes. Nature 362: 847-849.

Lu, X. and D.P. Lane. 1993. Differential induction of transcriptionally active p53 following UV or ionizing radiation: Defects in chromosome instability syndromes? Cell 75: 765778 . 
Macleod, K.F., N. Sherry, G. Hannon, D. Beach, T. Tokino, K. Kinzler, B. Vogelstein, and T. Jacks. 1995. p53-dependent and independent expression of p21 during cell growth, differentiation, and DNA damage. Genes \& Dev. 9: 935-944.

Meyn, M.S. 1995. Ataxia-Telangiectasia and cellular responses to DNA-damage. Cancer Res. 55: 5991-6001.

Morrow, D.M., D.A. Tagle, Y. Shiloh, F.S. Collins, and P. Hieter. 1995. TEL1, an S. cerevisiae homolog of the human gene mutated in ataxia telangiectasia, is functionally related to the yeast checkpoint gene MECl. Cell 82: 831-840.

Mortensen, R.M., D.A. Conner, S. Chao, A.A. Geisterfer-Lowrance, and J. G. Seidman. 1992. Production of homozygous mutant ES cells with a single targeting construct. Mol. Cell. Biol. 12: 2391-2395.

Mosner, J., T. Mummenbrauer, C. Bauer, G. Sczakiel, F. Grosse, and W. Deppert. 1995. Negative feedback regulation of wildtype p53 biosynthesis. EMBO I. 14: 4442-4449.

Nakanishi, M., G.R. Adami, R.S. Robertorye, A. Noda, S.F. Venable, D. Dimitrov, O.M. Pereira-Smith, and J.R. Smith. 1995. Exit from $\mathrm{G}_{0}$ and entry into the cell cycle of cells expressing p21 $1^{\text {Sdil }}$ antisense RNA. Proc. Natl. Acad. Sci. 92: 4352-4356.

Parker, S.B., G. Eichele, P. Zhang, A. Rawls, A.T. Sands, A. Bradley, E.N. Olson, J.W. Harper, and S.J. Elledge. 1995. p53independent expression of $\mathrm{p} 21^{\mathrm{Cipl}}$ in muscle and other terminally differentiating cells. Science 267: 1024-1027.

Paulovich, A.G. and L.H. Hartwell. 1995. A checkpoint regulates the rate of progression through $S$ phase in $S$. cerevisiae in response to DNA damage. Cell 82: 841-847.

Robertson, E.J. 1987. Embryo-derived stem cell lines. In Tera tocarcinomas and embryonic stem cells: A practical approach (ed. E.J. Robertson), pp. 71-112. IRL Press, Oxford, UK.

Savitsky, K., A. Bar-Shira, S. Gilad, G. Rotman, Y. Ziv, L. Vanagaite, D.A. Tagle, S. Smith, T. Uziel, S. Sfez, M. Ashkenazi, L. Pecker, M. Frydman, R. Harnik, R.P. Sankhavaram, A. Simmons, G.A. Clines, A. Sartiel, R.A. Gatti, L. Chessa, O. Sanal, M.F. Lavin, N.G.J. Jaspers, M.R. Taylor, C.F. Arlett, T. Miki, S.M. Weissman, M. Lovett, F. Collins, and Y. Shiloh. 1995. A single ataxia telangiectasia gene with a product similar to PI-3 kinase. Science 268: 1749-1753.

Shiloh, Y., E. Tabor, and Y. Becker. 1985. In vitro phenotype of ataxia-telangiectasia (AT) fibroblast strains: Clues to the nature of the "AT DNA lesion" and the molecular defect in AT. Kroc Found. Ser. 19: 111-121.

Smith, C.A., G.T. Williams, R. Kingston, E.J. Jenkinson, and J.J. Owen. 1989. Antibodies to CD3/T-cell receptor complex induce death by apoptosis in immature $\mathrm{T}$ cells in thymic cultures. Nature 337: 181-184.

Swift, M., P.J. Reitnauer, D. Morrell, and C.L. Chase. 1987. Breast and other cancers in families with ataxia-telangiectasia. N. Engl. J. Med. 316: 1289-1294.

Swift, M., D. Morrell, R.B. Massey, and C.L. Chase. 1991. Incidence of cancer in 161 families affected by ataxia-telangiectasia. N. Engl. I. Med. 325: 1831-1836.

Thacker, J. 1994. Cellular radiosensitivity in ataxia-telangiectasia. Int. I. Radiat. Biol. 66: S87-96.

Weinert, T. and D. Lydall. 1993. Cell cycle checkpoints, genetic instability and cancer. Semin. Cancer Biol. 4: 129-140.

Xiong, Y., G.J. Hannon, H. Zhang, D. Casso, R. Kobayashi, and D. Beach. 1993. p21 is a universal inhibitor of cyclin kinases. Nature 366: 701-704.

Xu, Y., T. Ashley, E.E. Brainerd, R.T. Bronson, M.S. Meyn, and D. Baltimore. 1996a. Targeted disruption of ATM leads to growth retardation, chromosomal fragmentation during meiosis, immune defects, and thymic lymphoma. Genes \& Dev. (this issue).
Xu, Y., L. Davidson, F.W. Alt., and D. Baltimore. 1996b. Deletion of the Igк light chain intronic enhancer/matrix attachment region impairs but does not abolish $V_{\kappa} J_{\kappa}$ rearrangement. Immunity 4: 377-385.

Zakian, V.A. 1995. ATM-related genes: What do they tell us about functions of the human gene? Cell 82: 685-687. 


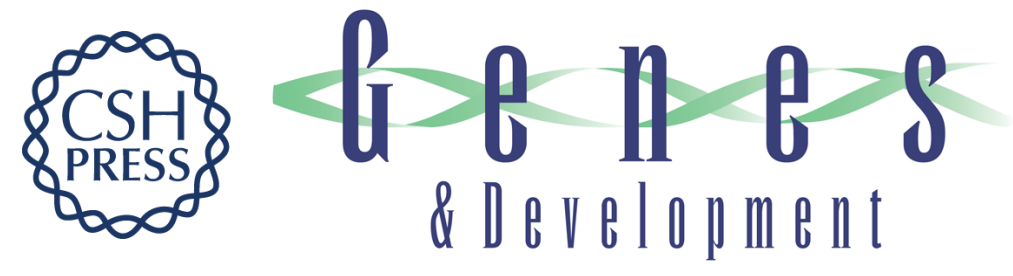

\section{Dual roles of ATM in the cellular response to radiation and in cell growth control.}

Y Xu and D Baltimore

Genes Dev. 1996, 10:

Access the most recent version at doi:10.1101/gad.10.19.2401

References This article cites 41 articles, 11 of which can be accessed free at:

http://genesdev.cshlp.org/content/10/19/2401.full.html\#ref-list-1

License

Email Alerting

Service

Receive free email alerts when new articles cite this article - sign up in the box at the top right corner of the article or click here.

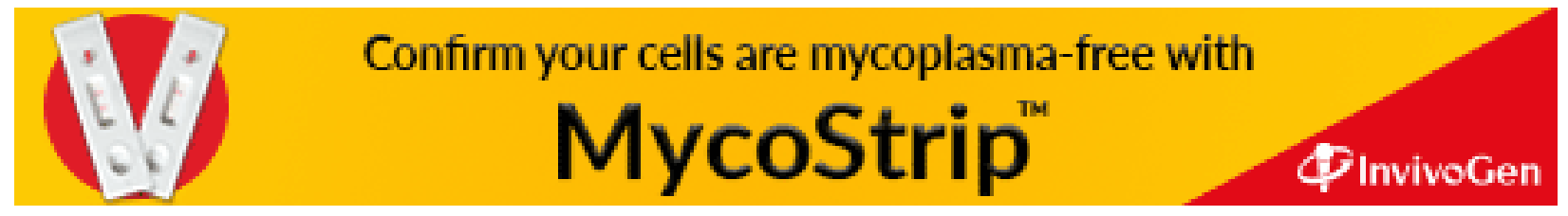

